\title{
The Internet and sexuality education: Tapping into the wild side
}

\author{
ELLEN F. ROSEN \\ College of William and Mary, Williamsburg, Virginia \\ and \\ LINDA C. PETTY \\ Hampton University, Hampton, Virginia
}

\begin{abstract}
To see whether observing information exchanges in "cyberspace" had a positive effect on computer usage and attitudes, students in an advanced undergraduate sexuality class were given an Internet project. Their pre- and postproject computer attitude and utilization reports were compared with those of a traditional computer usage research methods course taught by the same instructor. Overall, the e-mail/Internet project did not have a positive effect on computer usage and attitudes, whereas the more traditional computer as research tool usage taught in the methods class did have a positive effect.
\end{abstract}

Computers are an important tool for research and training. Experimental psychology courses often include units of instruction on the computer as a word processor or statistical analysis tool (Rosen, Feeney, \& Petty, 1994). The computer has also been used as an experiment simulator, allowing students to run themselves and others as subjects in classical experiments (Petty \& Rosen, 1990; St. James \& Schneider, 1991). In each of these modalities the computer serves as a tool for the individual student, enabling the person alone to be more productive. However, psychology is the science of human behavior, and humans are social animals by nature and usually work in groups. Computing in the "real world" also has this social function. For example, one of the most popular uses of Internet communications is for e-mail and chatting, both of which are human interactions facilitated by computer technology.

Computers have also been used to teach concepts in sexuality. Computer software has been used to present material about contraception (Reis \& Tymchyshyn, 1992) and has been used as a very successful "free-feeding," interactive, health information and decision-making source for adolescents (Hawkins, Gustafson, Chewning, Bosworth, \& Day, 1987).

An untapped area, however, is "cyberspace." "Cyberspace" is populated by human beings who are using the computer to communicate. This communication activity offers psychology students an unprecedented opportunity to sample directly how people are interacting with each other.

Teaching computer use as a means of communication might appeal more to nontraditional students. Nelson, Wiese, and Cooper (1991) report that women generally

Correspondence should be addressed to E. F. Rosen, 5023 Lauderdale Ave., Virginia Beach, VA 23455 (e-mail: efrose@mail.wm.edu). have less positive attitudes toward computers than men do, although men and women have equal computer abilities and problem-solving skills. Women tend to have less knowledge and less interest in computers than do men, as well as less computer experience. Nelson et al. (1991) argue that this difference in experience between men and women accounts for attitudinal differences. Their survey of the literature indicates that there is a strong positive relationship between computer experience and favorable computer attitudes. They found that women who thought of the computer as a machine were more likely to drop out of a computer course. Generally, students who remained in the course were more likely to use personal names for the computer as the semester went on. They found further that women who stayed in the course came to think of computers as a personal productivity tool. Thus, women seem to need to see the computer as a tool that is useful for them in order to be willing to stick to learning computer usage.

E-mail has become one of the most popular uses of computer networks. McCormick and McCormick (1992) collected students' electronic mail at their university over a one-semester period. Before beginning this collection, they posted a notice to all e-mail users that the electronic mail system was not private and that their mail might be read by other people. The students were mostly male computer science students. McCormick and McCormick reported that over $50 \%$ of the mail was devoted to social activity. They categorized this mail into less intimate (greetings, threats, put-downs, crude flirting, humorous, and symbolic) and more intimate (social plans, news, courtship, relationship maintenance, and love messages) communications. These two categories were equally frequent. This self-disclosure occurred in spite of the warning that was given by the system that the mail could be read by anyone. The researchers suggested that this might be a result of the anonymity provided by the medium. They 
also report that women in their sample were twice as likely to receive electronic mail than were men.

E-mail is also used to teach courses. Rogers (1989), who has reported on a course in human resource management, argues that electronic computer mail offers many valuable teaching features: privacy, individualization, and asynchronous interaction. These features are clearly important for personal interaction between the teacher and learner. Rogers states that these are the very properties required for the humanization of the teaching-learning process.

Enns (1993) asserts that women learn via the process of connected knowing, which is a different type of learning situation from that provided in the typical course. Separate knowing is the type of learning that is fostered or developed by the lecture-written examination system. Activities that nurture connected knowing are those that involve active exploration and discussion of feelings and personal relatedness to the material. Use of the computer as an interpersonal communication device instead of a computational device should appeal to the need for connected knowing. Since psychology courses usually have a preponderance of female students, it was hypothesized that emphasizing the computer as a communication device, as a way to share feelings and interact with other human beings, as opposed to more traditional usage, would lead to a more positive attitude toward the computer at the end of the semester.

To test this hypothesis, a computer mailing list was established for a class in human sexuality. These students were also assigned the task of finding interesting sexual information on discussion lists in the Usenet archives or Gopher systems and sharing the material by using the class list. It was predicted that these students would show a greater increase in positive attitudes toward computer usage at the end of the semester than would students in a class in which the computer was used in a more traditional way (statistical analysis and word processing).

\section{METHOD}

\section{Subjects}

The subjects were students enrolled in either a course in human sexuality or a course in research methods. The sexuality class $(N=$ 31 ), an elective, comprised, primarily, senior psychology majors; the research methods class $(N=40)$ is required for the major, and most students were sophomores intending to be psychology majors. It is a writing-intensive course with a laboratory section.

\section{Procedure}

Both classes were asked to fill out a questionnaire about their attitudes, experience, and plans for future computer activity at the first class meeting. The same questionnaire was repeated at the end of the semester. The human sexuality class was only required to use the computer network system to access Internet and to join a class electronic mailing list. They were assigned the task of searching Internet to find something of relevance to the term paper topic that they had selected, which they were then to post to the list. Instruction in the procedures was given in the computer laboratory at the beginning of the semester. The methods class learned how to use the computer to write APA-style reports and had a brief intro- duction to the use of SPSS (Statistical Package for the Social Sciences). They also used the MEL (Micro Experimental Laboratory) student package. The first author also used a ToolBook presentation on a 35-in. monitor in the methods classroom to supplement her lectures. This presentation material was made available to the methods students in the computer laboratory for review purposes.

\section{RESULTS}

A summary of the means of the responses to the questionnaire by the two classes is presented in Table 1 . Not all students completed all the questions, so the sample sizes vary from question to question. The responses were recoded in such a fashion that 7 indicates maximum agreement with the question and 1 the least agreement. In order to control for possible initial differences between the two classes, difference scores were calculated by subtracting the posttest response from the pretest response to the item. Then independent $t$-test analyses were performed on all the differences comparing the two groups. The $t$ values and significance levels are also presented in Table 1.

The significant statistical results obtained for several of the questions indicate that the methods students felt that they gained more computer experience during the semester than did the sexuality students. The methods students also indicated a greater desire to learn more computer applications and showed a greater increase in the belief that the computer would help them with the course work (the sexuality students in fact felt less belief in the computer's ability to help them by the end of the semester). Similarly, the sexuality class increased their feelings of ineptness by the end of the semester, whereas the methods class students showed a decrease in their feelings of ineptness. The methods students gained more in terms of feeling that they were skillful in their computer usage. Finally, they had a greater decrease in anxiety about taking a math course by the end of the semester than did the sexuality students.

A chi-square analysis was done of the breakdown of gender by class. There were 27 females and 13 males in the methods class and 27 females and 4 males in the sexuality class. This breakdown was not quite significant $\left[\chi^{2}(1)=3.68, p<.055\right]$. To determine whether gender had any effect, the questionnaire item scores, both pretest and posttest, were correlated with gender. The only correlation with gender that was significant was that for the pretest question about computers having relevance.

Some multiple regression analyses were performed as well. A good predictor of initial positive feelings about computing was provided by the combination of the pretest items regarding amount of experience, the level of computer anxiety, and feelings of ineptness. Together, they yield a multiple $R$ of 76 . All three of these predictors were significant. The regression analysis and the beta weights are presented in Table 2 . The same model, with the posttest items in place of the pretest measures, was not as good at predicting feelings at the end of the semester (multiple $R$ of .62). This regression analysis is also presented 
Table 1

Average Degree of Agneement to Survey Questions ( 7 = Maximum Agreement) for Methods and Sexuality Students and Paired Comparisons of Preclass-Postclass Change Scones

\begin{tabular}{|c|c|c|c|c|c|c|c|}
\hline \multirow[b]{2}{*}{ Question } & \multicolumn{2}{|c|}{ Methods Class } & \multicolumn{2}{|c|}{ Sexuality Class } & \multirow[b]{2}{*}{$t$} & \multirow[b]{2}{*}{$d f$} & \multirow[b]{2}{*}{$p$} \\
\hline & Pre & Post & Pre & Post & & & \\
\hline I have a lot of computer experience. & 3.6 & 4.6 & 4.0 & 4.3 & -3.95 & 55 & .001 \\
\hline $\begin{array}{l}\text { Computers have relevance to my } \\
\text { life. }\end{array}$ & 4.7 & 5.2 & 4.9 & 4.7 & -1.67 & 54 & n.s. \\
\hline $\begin{array}{l}\text { My feelings about computers are } \\
\text { very positive. }\end{array}$ & 4.2 & 4.8 & 4.7 & 4.9 & -1.65 & 55 & n.s. \\
\hline $\begin{array}{l}\text { I want to learn as many computer } \\
\text { applications as possible. }\end{array}$ & 4.7 & 5.0 & 5.3 & 5.3 & -2.32 & 53 & .024 \\
\hline $\begin{array}{l}\text { The computer can help me gain a } \\
\text { better understanding of the subject } \\
\text { matter. }\end{array}$ & 4.4 & 4.6 & 4.3 & 3.8 & -1.85 & 46 & n.s. \\
\hline $\begin{array}{l}\text { The computer will help me do my } \\
\text { work for this course. }\end{array}$ & 4.5 & 5.6 & 4.6 & 4.0 & -3.69 & 45 & .001 \\
\hline $\begin{array}{l}\text { If I were teaching this course, I } \\
\text { would not include any computer } \\
\text { usage. }\end{array}$ & 2.9 & 2.3 & 3.7 & 4.4 & 1.84 & 44 & n.s. \\
\hline I am computer anxious. & 4.2 & 3.6 & 3.6 & 3.8 & 1.63 & 50 & n.s. \\
\hline $\begin{array}{l}\text { I am inept with any kind of } \\
\text { mechanical device. }\end{array}$ & 3.0 & 2.4 & 2.4 & 2.7 & 2.34 & 54 & .023 \\
\hline $\begin{array}{l}\text { I am skillful with computer } \\
\text { programs. }\end{array}$ & 3.2 & 4.1 & 3.7 & 3.9 & -2.31 & 54 & .025 \\
\hline $\begin{array}{l}\text { I like to do my studying and work } \\
\text { alone. }\end{array}$ & 4.7 & 5.6 & 4.8 & 5.0 & -1.29 & 53 & n.s. \\
\hline $\begin{array}{l}\text { I am anxious about taking math } \\
\text { courses. }\end{array}$ & 4.2 & 3.6 & 3.6 & 3.8 & 0.32 & 54 & n.s. \\
\hline $\begin{array}{l}\text { I must see the relevance of } \\
\text { something in order to be able to } \\
\text { understand it. }\end{array}$ & 4.3 & 4.6 & 4.4 & 4.3 & -1.67 & 54 & n.s. \\
\hline $\begin{array}{l}\text { I can learn things easily on my } \\
\text { own. }\end{array}$ & 4.6 & 4.9 & 5.2 & 5.2 & -0.46 & 54 & n.s. \\
\hline $\begin{array}{l}\text { I think that the Internet is very } \\
\text { helpful. }\end{array}$ & 5.2 & 5.1 & 5.4 & 4.7 & & & \\
\hline Course grade $(\mathrm{A}=4.0)$ & & 3.1 & & 3.44 & & & \\
\hline
\end{tabular}

in Table 2 . Now only computer anxiety is a significant predictor. Using the pretest variables to predict feelings as reported on the posttest yielded a multiple $R$ of .50 , with only pretest computer anxiety being a significant predictor. This analysis is also summarized in Table 2.

\section{DISCUSSION}

Generally, the Internet introduction and assignment had very little effect on the attitudes toward computing applications and their benefits for the sexuality students. The students did not seem to find the use of Internet attractive and felt even less that the computer could help them with the course subject matter. This was not true for the methods students, who generally had more positive attitudes toward computer usage and felt less mechanically inept and computer anxious than they did at the beginning of the term.

This lack of larger positive effect for the sexuality versus the experimental students may have been due to the sexuality students' putting off the work until the end of the semester when it became difficult to access Internet because of the increasing popularity of e-mail. The experimental students, who were not using Internet, did not have this access problem. Another problem was that only some of the computers would connect successfully to the college backbone, so that students could not discriminate their failures from equipment failures. Also, Gopher and P-Mail, the programs used at William and Mary, are not user friendly. Public Internet access is not yet well developed. As long as access remains nonintuitive, Internet usage will not be viewed as a positive, pleasing learning experience by noncomputer science students except in a few individual cases.

Finally, much "X-Rated" sexual activity is available through the national network system. Usenet has a series of alternative discussion groups (newsgroups) which essentially consist of text-based pornography. Earnest "hacker-type" students in a sexuality class will undoubtedly come across such materials. To control such material, the class discussion group (listserv) must be moderated by the instructor and must be restricted to the class. This slows all exchanges down. On the basis of the present results, and the amount of effort required of the 
Table 2

Multiple Regression Analyses of Pre- and Posttest Item Responses Collapsed Across Classes

\begin{tabular}{|c|c|c|c|c|c|c|}
\hline Dependent Variable & Multiple $R$ & $R^{2}$ & Predictor Variable & Beta & $t$ & Significance \\
\hline Pretest feelings & .76 & .58 & $\begin{array}{l}\text { Pretest experience } \\
\text { Pretest computer anxiety } \\
\text { Pretest mechanically inept } \\
\text { Constant }\end{array}$ & $\begin{array}{r}.339 \\
-.263 \\
-.321\end{array}$ & $\begin{array}{r}2.79 \\
-2.46 \\
-3.31 \\
5.05\end{array}$ & $\begin{array}{l}.007 \\
.017 \\
.002 \\
.001\end{array}$ \\
\hline Posttest feelings & .62 & .38 & $\begin{array}{l}\text { Posttest experience } \\
\text { Posttest computer anxiety } \\
\text { Posttest mechanically inept } \\
\text { Constant }\end{array}$ & $\begin{array}{r}.101 \\
-.556 \\
.02\end{array}$ & $\begin{array}{r}0.69 \\
-3.52 \\
0.12 \\
5.91\end{array}$ & $\begin{array}{l}\text { n.s. } \\
.001 \\
\text { n.s. } \\
.001\end{array}$ \\
\hline Posttest feelings & .50 & .25 & $\begin{array}{l}\text { Pretest experience } \\
\text { Pretest computer anxiety } \\
\text { Pretest mechanically inept } \\
\text { Constant }\end{array}$ & $\begin{array}{r}.135 \\
-.344 \\
-.161\end{array}$ & $\begin{array}{r}.80 \\
-2.26 \\
-1.17 \\
5.62\end{array}$ & $\begin{array}{l}\text { n.s. } \\
.028 \\
\text { n.s. } \\
.001\end{array}$ \\
\hline
\end{tabular}

instructor, the Internet exercise has been put on hold until a more user-friendly system becomes available on the college computer network.

Gender was not found to be related to most of the variables measured. This could have been a result of the small number of men in either of the two classes. The lack of gender effects did not match expectations based on the literature, which stresses differential experience for males and females (McCormick \& McCormick, 1992). It may be that males in social science courses also are less computer experienced. On the other hand, computer experience, computer anxiety, and feelings of ineptness proved to be good predictors of positive attitudes toward computers. This latter finding does match reports in the literature on the role of prior experience and anxiety (Nelson et al., 1991). Again, gender did not improve the predictive power of these variables.

\section{REFERENCES}

ENNs, C. Z. (1993). Integrating separate and connected knowing: The experiential learning model. Teaching of Psychology, 20, 7-13.

Hawkins, R. P., Gustafson, D. H., Chewning, B., Bosworth, K., \&
DAY, P. (1987). Reaching hard-to-reach populations: Interactive computer programs as public information campaigns for adolescents. Journal of Communication, 37, 8-28.

MCCormick, N. B., \& MCCormick, J. W. (1992). Computer friends and foes: Content of undergraduates' electronic mail. Computers in Human Behavior, 8, 379-405.

Nelson, L. J., WiESE, G. M., \& CoOper, J. (1991). Getting started with computers: Experience, anxiety, and relational style. Computers in Human Behavior, 7, 185-202.

PeTTY, L. C., \& Rosen, E. F. (1990). Increase in mastery levels using a computer-based tutorial/simulation in experimental psychology. Behavior Research Methods, Instruments, \& Computers, 22, 289-291.

ReIs, J., \& TYMChyshyN, P. (1992). A longitudinal evaluation of computer-assisted instruction on contraception for college students. Adolescence, 27, 803-811.

ROGERS, G. (1989). Teaching a psychology course by electronic mail. Social Science Computer Review, 7, 60-64.

Rosen, E. F., Feeney, B., \& Petty, L. C. (1994). An introductory statistics class and examination using SPSS/PC. Behavior Research Methods, Instruments, \& Computers, 26, 242-244.

ST. JAMES, J. D., \& SCHNEIDER, W. (1991). Student MEL software support for instructors and teaching assistants in research methods course. Behavior Research Methods, Instruments, \& Computers, 23, 149-154.

(Manuscript received November 14, 1994; revision accepted for publication January 31,1995 .) 